\title{
Gel Penetrate-blotted Immunobinding Assay, a Novel Method for Serological Detection of Fusarium spp. in Soil
}

\author{
Tsutomu ARIE, Yoshio HayASHI, ${ }^{*}$ Katsuyoshi Yoneyama* and Isamu Yamaguchi \\ The Institute of Physical and Chemical Research (RIKEN), Hirosawa 2-1, Wako 351-01, Japan \\ ${ }^{*}$ Faculty of Agriculture, Meiji University, Higashimita 1-1-1, Tama-ku, Kawasaki 214, Japan
}

(Received February 17, 1997 ; Accepted June 27, 1997)

\begin{abstract}
A new serological method for the detection of Fusarium spp. in soil was established. On a sheet of nitrocellulose membrane, about $1 \mathrm{~mm}$ thick layer of agar gel was overlaid, and soil sample suspension was spread over the gel. After 10 to $20 \mathrm{hr}$ of incubation, fungi in the sample grew through the gel-layer and reached the membrane leaving the soil particles on the gel surface. The membrane blotted with the fungi was recovered, and was treated with a monoclonal antibody API9-2 against Fusarium spp., secondary antibody labeled with alkaline phosphatase, and finally the substrate solution. The samples of Fusarium-infested soil successfully showed positive reaction on the membrane by this immunobinding assay (IBA). We named the method as gel penetrate-blotted immunobinding assay (GP-IBA). As the series of assay procedures can be completed within $24 \mathrm{hr}$ and the detection limit is estimated to be about $10^{3}$ conidia/g soil, this method is considered to be suitable for detection of Fusarium spp. in soil.
\end{abstract}

\section{INTRODUCTION}

Soilborne diseases, especially those due to Fusarium spp., cause serious problems on cultivating crops. To control the diseases, use of soil fumigants such as chloropicrin, D-D (a mixture of 1,3-dichloropropene, 1,2dichloropropane, and related hydrocarbons), or methyl bromide has been in practice. Because of the risks, involved in using these chemicals, such as unfavorable impact on the environment and soil becoming vulnerable to pathogens, one should be careful about the timing of the treatment and the dose of the fungicide. ${ }^{1)}$

Several ways of biological control of soilborne diseases using non-pathogenic fungi or anti-fungal microorganisms have been reported. ${ }^{1-4)}$ As the disadvantage in biological control of diseases is its insecurity, integrated pest management (IPM) with chemical and/or biological methods is necessary depending upon the actual pathogen level in the soil as well as in the seedlings.

For the detection of soilborne pathogenic fungi in soil, few methods have been reported other than selective media or those with susceptible indicator plants. ${ }^{5-7}$ But they are sometimes time-consuming and not practical for rapid and accurate assay. Therefore, development of some good detection methods is called for.

Immunological methods are now widely used not only in medical examination but also in plant diagnosis because of their high reaction specificity, rapidity and reliability. ${ }^{8-10)}$ Polyclonal antibodies or monoclonal antibodies (MAbs) are reported to be useful to detect plant pathogenic fungi including soilborne pathogens such as Phytophthora sp., ${ }^{11,12)}$ Pythium sp., ${ }^{13,14)}$ Plasmodiophora brassicae, ${ }^{15-17)}$ Fusarium sp., ${ }^{18)}$ and Rhizoctonia solani ${ }^{9)}$ in plant tissues.

Previously we reported methods for the detection of Fusarium spp. in plant tissues by immunofluorescence assay (IFA) ${ }^{18)}$ and direct-tissue blotted-immunobinding assay (DT-IBA) ${ }^{18)}$ with MAb API9-2, ${ }^{19)}$ which is one of MAbs reacting specifically with the genus Fusarium. Using the MAb, immunoassays such as ELISA or DIBA with soil suspension were assessed in preliminary experiments; however, they were successful only when a high number of propagula $\left(10^{8-9} \mathrm{cfu} / \mathrm{g}\right.$ soil $)$ of pathogen exists in the soil sample. Since such a high population of Fusarium spp. is not a common occurrence, it is required to develop a new serological method for soil diagnosis. The failure in detection of the less propagula might be due to adsorption of immunoprotein on soil particles. To prevent this non-specific reaction between antibody and soil particles, separation of fungi from soil particles is necessary for applying serological diagnostic tests to soil. However, it is very difficult to isolate fungi from soil with ordinary physical methods, such as density gradient or sieving. 
This paper deals with a new method to separate fungi from soil particles with a layer of agar gel in contact with a piece of membrane, and a serological way to specifically detect Fusarium spp. on the membrane.

\section{MATERIALS AND METHODS}

\section{Monoclonal Antibody (MAb)}

Hybridoma clone API9-2 was used as a producer of a Fusarium spp.-specific MAb. ${ }^{19)}$ Supernatant fluid containing the MAb was prepared by the method already established ${ }^{18)}$ and was used after diluting with FTBS (TBS, $10 \mathrm{mM}$ Tris- $\mathrm{HCl}$ [pH 7.4] and $140 \mathrm{mM} \mathrm{NaCl}$, containing $10 \%[\mathrm{v} / \mathrm{v}]$ fetal calf serum). The binding site of MAb API9-2 was identified to be on the surface of mycelia of Fusarium spp. ${ }^{18)}$

\section{Fungal Isolates and Preparation}

For artificial infestation of soil, $F$. oxysporum Schlechtend. : Fr. f. sp. lycopersici (Sacc.) Snyd. \& Hans. race 2 (880621a-1), a causal pathogen of tomato wilt and Verticillium dahliae Kleb. (910312a-1), a pathogen of Verticillium wilt of eggplant and tomato, were used. These isolates were cultured on potato dextrose broth (PDB) medium, which consists of $0.7 \mathrm{~g}$ of freeze-dried mashed-potato (Snow Brand, Sapporo) and $0.5 \mathrm{~g}$ of dextrose in $100 \mathrm{ml}$ of tap water, in a $300 \mathrm{ml}$ of Erlenmeyer flask on a rotary shaker (Bio-Shaker, BR-3000, Taitec, Saitama) at $120 \mathrm{rpm}, 27^{\circ} \mathrm{C}$ for about 4 days. After incubation, the culture fluid was centrifuged $(3000 \times g, 15 \mathrm{~min})$ to collect conidia, and inoculum was prepared at a concentration of about $10^{7} \mathrm{cfu} / \mathrm{ml}$ with 0.1 $\mathrm{M}$ phosphate buffered saline (PBS; $\mathrm{pH} 7.5$ ).

\section{Soils}

Commercial gardening soil (Kureha-soil, Kureha Chemical Industry, Tokyo) was sterilized by autoclaving $\left(121^{\circ} \mathrm{C}, 40 \mathrm{~min}\right)$ and was artificially infested with the pathogens by pouring the desired amount of inocula to pots with the soil.

We also examined soil samples from tomato field of Imaichi, Tochigi, which were severely infested with $F$. oxysporum f. sp. lycopersici. These infested soils and sterilized soil were mixed in different ratios $(1: 4 ; 1: 49$; $1: 499 ; 1: 4999 ; 1: 49,999 ; 1: 499,999 ; 1: 4,999,999)$ to prepare a series of soils with decreasing population of the pathogen. As a control, non-infested soil sampled from a healthy tomato field in Imaichi was used without sterilization.

For GP-IBA, $1 \mathrm{~g}$ of each test soil was suspended in 5 $\mathrm{ml}$ of PBS and mixed thoroughly by voltexing, followed by $1 \mathrm{hr}$ of incubation at room temperature.

\section{Gel Penetrate-blotting System (GP-system)}

A piece of gel layer $(3 \times 4 \mathrm{~cm}$ and ca. $1 \mathrm{~mm}$ in thickness) of potato dextrose agar (PDA, PDB containing

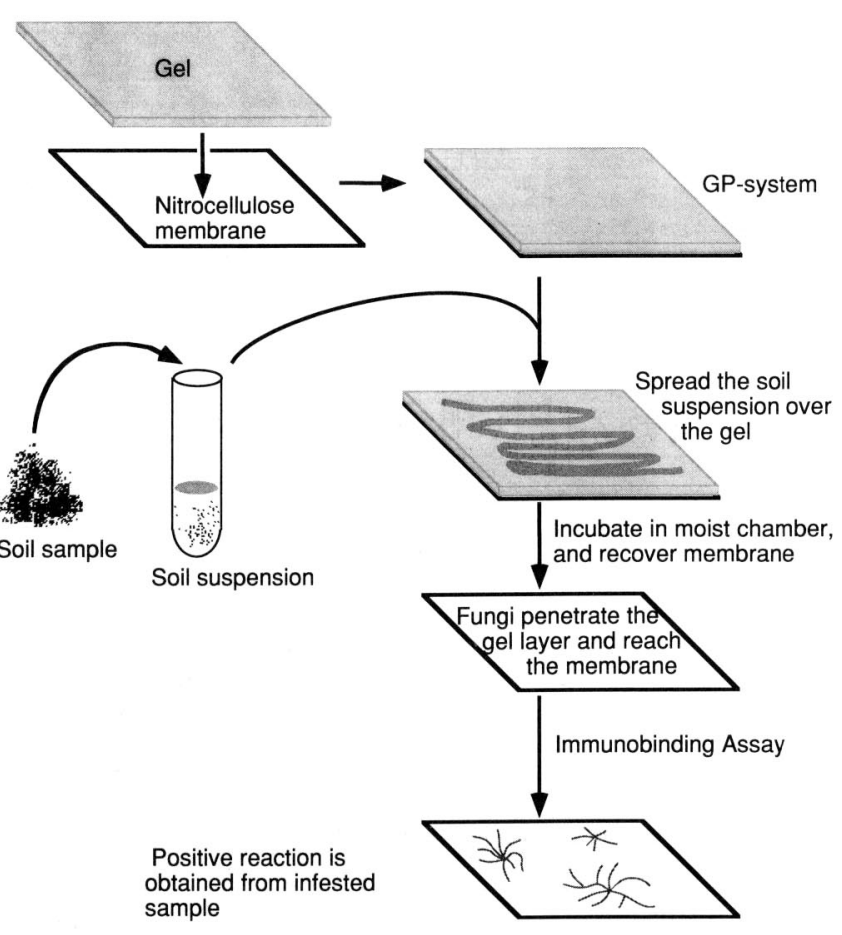

Fig. 1 Pictorial explanation of gel penetrate-blotted immunobinding assay (GP-IBA).

$1.5 \%[\mathrm{w} / \mathrm{v}]$ agar) was cut from a plate medium and was laid over a piece of $0.45 \mu \mathrm{m}$ pore size nitrocellulose membrane $(3 \times 4 \mathrm{~cm}$, Trans-Blot Transfer Medium, BioRad Laboratories, Richmond, CA, U.S.A.) with care to avoid air bubbles between them (Fig. 1). Then this GP-system was kept in a plastic petri dish under highhumidity conditions with a sheet of filter paper immersed in distilled water.

\section{Gel Penetrate-blotted Immunobinding Assay (GP- IBA)}

Soil suspension was prepared as mentioned above, and $100 \mu 1$ of each sample was spread over the gel layer of GP-system. After 10 to $20 \mathrm{hr}$ of incubation at $27^{\circ} \mathrm{C}$ under humidified conditions, the membrane was separated from the gel and blocked with FTBS containing $1 \%$ $[\mathrm{w} / \mathrm{v}]$ bovine serum albumin (BSA), for $1 \mathrm{hr}$ at room temperature. After blocking, it was incubated with MAb API9-2, diluted with TBS, at room temperature for $1 \mathrm{hr}$. Following three washes with TBST (TBS containing $0.1 \%[\mathrm{v} / \mathrm{v}]$ Tween 20 ), the blot was incubated with 2000 times dilution of the secondary antibody (goat anti mouse IgM, Zymed Co., So. San Francisco, CA., U.S.A.) conjugated with alkaline phosphatase for $1 \mathrm{hr}$ at room temperature. Then, the membrane was washed three times, $5 \mathrm{~min}$ each, with $200 \mathrm{ml}$ of PBST, and was immersed in AP-buffer ( $100 \mathrm{mM}$ Tris, $100 \mathrm{mM} \mathrm{NaCl}$, and 5 $\mathrm{mM} \mathrm{MgCl}_{2}$ ) containing 5-bromo-4-chloro-3-indolyl phosphate (BCIP color development substrate, Promega, Madison, WI, U.S.A.) and nitro blue tetrazolium (NBT 
color development substrate, Promega) for color development. Presence of pathogen was indicated by the development of blue color on the membrane.

\section{Conventional Diagnosis Methods}

In order to compare credibility of GP-IBA method with the conventional methods, in planta assay and the isolation test with a selective medium were performed.

\subsection{In planta test with indicator plants}

For the indirect assay of Fusarium-infestation of the field soil, in planta assay6) was carried out with cv. Momotaro, a susceptible cultivar of tomato (Lycopersicon esculentum Mill., Takii Seeds, Kyoto). Each soil with various population of the pathogen was taken in plastic pots, and seeds were sown. The pots were maintained in a phytotron that is controlled at $26^{-}-29^{\circ} \mathrm{C}$, $50 \%$ humidity, $12 \mathrm{hr}$ light $(10,000-30,000 \mathrm{~lx})$ and $12 \mathrm{hr}$ dark conditions. Forty-five days after seeding, the disease severity (disease index: $0-3$ ) of each plant was assessed by symptoms developed on the plants.

\subsection{Estimation of population of Fusarium spp. with a} selective medium

To estimate the population of Fusarium spp. in soil, a selective medium, Komada's medium, ${ }^{5-7)}$ made of $0.1 \%$ $\mathrm{K}_{2} \mathrm{HPO}_{4}, \quad 0.05 \% \quad \mathrm{KCl}, \quad 0.05 \% \quad \mathrm{MgSO}_{4} \cdot 7 \mathrm{H}_{2} \mathrm{O}, \quad 0.001 \%$ Fe(III)-EDTA, $0.2 \%$ L-asparagine monohydrate, $2 \%$ Dgalactose, a.i. $0.075 \%^{6}$ ) pentachrolonitrobenzene (PCNB, 1000 times diluted Earthcide 75WP; Nissan Chemical Industries, Tokyo), and $0.05 \%$ sodium cholate (Tokyo Kasei, Kita, Tokyo), was used. Soil suspension was spread over the medium and was incubated at $27^{\circ} \mathrm{C}$ for 9 days. The number of the colonies that appear like Fusarium spp. ${ }^{5)}$ was counted and the population in soil was estimated. ${ }^{201}$

\section{RESULTS AND DISCUSSION}

After spreading the soil-suspension onto the gel layer, 10 to $20 \mathrm{hr}$ incubation was enough to allow the growing fungal mycelia to penetrate the gel and reach the membrane under it. However, the resting form of $F$. oxysporum, chlamydospore, requires about $10 \mathrm{hr}$ just to germinate, so, 20-hr incubation is better to get more accurate results with the field's soil sample. Many species of fungal propagula possibly present in the soil might also be blotted on the membrane, but as MAb API9-2 reacts specifically with the genus Fusarium, only those belonging to this genus blotted on the membrane were detected after the immunobinding assay (IBA) using the MAb API9-2.

As shown in Fig. 2, when $F$. oxysporum f. sp. lycopersici-infested soils were tested, the colonies of Fusarium spp. became visible on the membrane by immunostaining, showing a mycelial pattern of the blot (Fig. 2-5, indicated by an arrow). The more propagula of Fusarium spp. in the soil established the stronger reactions was observed depending on the mycelial density (Fig. 2-1, 2, and 3). The samples without infestation (Fig. 2-8) and infested with $V$. dahliae showed no reaction.

With this blotting system, the fungi in soil were sieved from soil particles through a gel layer due to the intrinsic nature of most of the fungi; While the soil particles stayed on the surface of the gel layer, the fungi could grow to penetrate the gel with mycelial elongation. So, we named this method as gel penetrate-blotted immunobinding assay (GP-IBA).

GP-IBA requires only 15 to $24 \mathrm{hr}$ from preparing soil suspension to achieve the final results. Conventionally, it has been difficult to isolate Fusarium spp. in soil for detection except with some Fusarium-selective media, but GP-IBA with MAb API9-2 offers us an easy way to isolate and detect Fusarium spp. in soil distinctly from the other genera of fungi. Further, this method takes much less time to get the results than any other method so far reported, such as isolation with Fusarium-selective media or in planta assay with the indicator plants.

Recently, another novel method for the separation of Phytophthora infestans from soil was reported. ${ }^{12)}$ This method also exploits the pathogen's biological feature, i.e., when the sample soil is soaked with water, zoospores

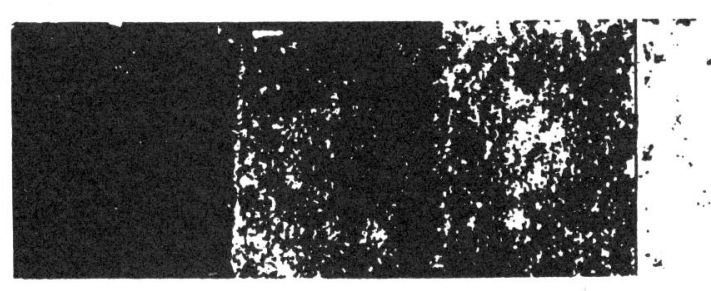

1

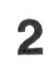

3

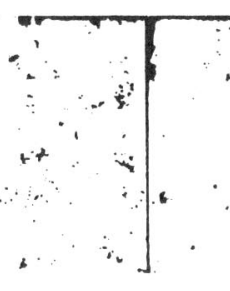

4

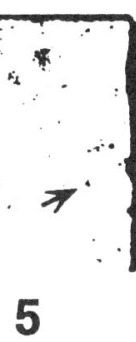

5

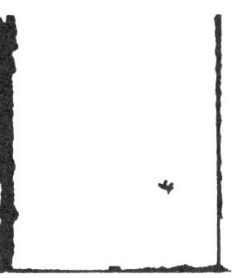

6

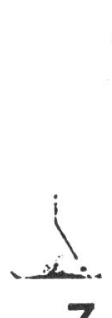

7

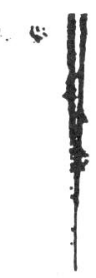

8

Fig. 2 GP-IBA of artificially Fusarium-infested soil.

$\mathbf{1}, 10^{7}$ conidia/g soil $; \mathbf{2}, 10^{6}$ conidia/g soil $; \mathbf{3}, 10^{5}$ conidia/g soil $; \mathbf{4}, 10^{4}$ conidia/g soil $; \mathbf{5}, 10^{3}$ conidia/g soil $; \mathbf{6}, 10^{2}$ conidia/g soil $; \mathbf{7}, 10^{1}$ conidia/g soil $; \mathbf{8}$, soil without infestation. Ten hour incubation after spreading the soil suspension onto the gel layer of GP-system, following IBA with Fusarium-specific monoclonal antibody API9-2. The color spot showing positive reaction consists of mycelial blot (ex. 5, indicated by an arrow). More than five replicates were used and one of the results is shown. 


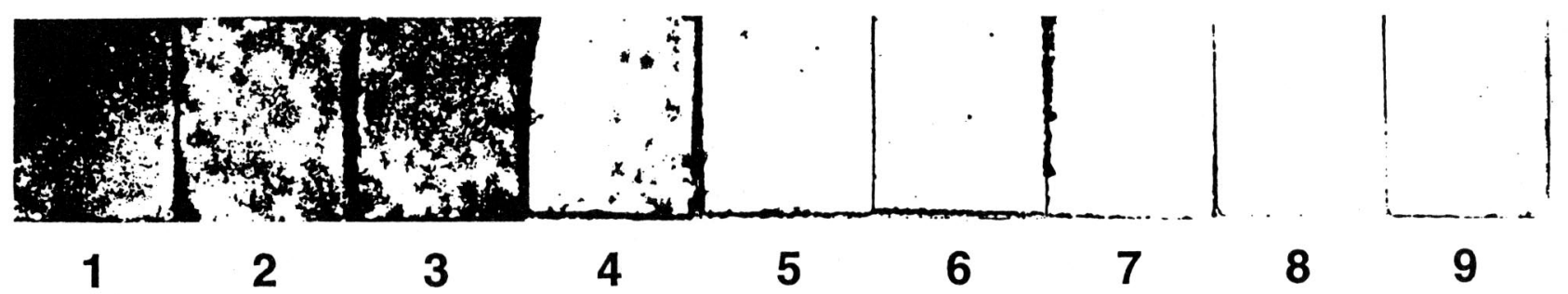

Fig. 3 GP-IBA of Fusarium-infested tomato field's soil.

$\mathbf{1}$, original field's soil $; \mathbf{2}$, the field's soil and sterilized soil was mixed at the ratio of $1: 4 ; \mathbf{3}, 1: 49 ; \mathbf{4}, 1: 499 ; \mathbf{5}, 1: 4999 ; \mathbf{6}, 1$ : 49,$999 ; 7,1: 499,999 ; 8,1: 4,999,999 ; 9$, healthy field's soil. Twenty hour incubation after applying the soil suspension on to GP-system. More than five replicates were used and one of the results is shown.

Table 1 Detection of Fusarium spp. in soil by methods with selective medium and indicator plant.

\begin{tabular}{l} 
Assay method \\
\cline { 2 - 8 }
\end{tabular}

released into the water phase are trapped by a slip of membrane immersed in the water to be used for immunodetection. It suggests that basic biological features are invaluable for developing new methods of this kind.

Since $10^{3}$ to $10^{5}$ conidia of pathogenic $F$. oxysporum in a gram of soil are needed to cause wilt disease in tomato plants, ${ }^{7)}$ the inferior limit of GP-IBA, estimated at about $10^{3}$ conidia/g soil as shown in Fig. 2, appears sensitive enough for the soil diagnosis. To test the applicability of GP-IBA for the field diagnosis, then we performed the assay on a severely Fusarium-infested tomato field's soil using MAb API9-2. The soil showed strong positive reaction even when it was mixed with sterilized-soil at the ratio of $1: 49$ (Fig. 3-1, 2, and 3). Moderate reaction was observed in the sets of $1: 499,1: 4999$, and $1: 49,999$ mixtures (Fig. 3-4, 5, and 6). The population of Fusarium spp. in the original field's soil was estimated to be around $10^{7}$ conidia/g soil by comparing the strength of color development with that of the artificially infested soil (Fig. 2). When the field soil was assessed by in planta assay with indicator plants, test plants showed severe symptoms in the soil mixed with the sterilized-soil at $1: 4,1: 49$; moderate symptoms in the $1: 499,1$ : 4999, and, $1: 49,999$; no symptom in further mixture (Table 1). The results obtained by GP-IBA were more corresponding to in planta test than that of Komada's medium method (Table 1).
This GP-IBA method to detect Fusarium spp. in soil may be applicable to field diagnosis. However, since MAb API9-2 used in this report reacts with every species or isolates of Fusarium spp., ${ }^{19)}$ we might have detected all the strains of Fusarium spp. including some pathotypes (formae or races) and/or non-pathogenic strains in the field's soil. But again, the fact that healthy field's soil showed no positive reaction by GP-IBA and selective medium method (Table 1 and Fig. 3-9) suggests that bulk of Fusarium spp. in soil is mostly comprised of pathogenic forms in this study.

The purpose of the field diagnosis is to affirm whether disease will occur when plants are cultivated in that field. Therefore, the diagnosis with MAb API9-2 is sometimes not conclusive. To make the immunoassay of Fusarium spp. more specific, the production of $\mathrm{MAb}$ that reacts specifically to each pathogenic form (f. sp.) or each race of the f. sp. is desired. The GP-IBA method that we offer in this paper would be more advantageous if more specific antibodies could be obtained.

In order to estimate the population of Fusarium spp. in soil, we tried to see the strength of the developed color in figures by using a colorimeter (NR-3000, Nippon Denshoku Co., Sengoku, Bunkyo, Tokyo). Although in the case of a large Fusarium-population, color density and population were correlated, the method did not work well in the case of a smaller Fusarium-population (data 
not shown), possibly due to the unequal distribution of the colonies on the membrane as can be seen in Fig. 3-4.

Soilborne Fusarium diseases are still a major threat for vegetable farming. For the IPM of Fusarium diseases, diagnosis of Fusarium infestation of the field plays an important role, and sensitive and quicker method like GP-IBA are suited for this purpose.

\section{ACKNOWLEDGMENT}

This work was supported financially in part by a grant aid from the Ministry of Education, Science, Sports and Culture, Japan and a grant for "Biodesign Research Group" from The Institute of Physical and Chemical Research (RIKEN). The authors wish to express their thanks to Dr. T. Kijima, Tochigi Prefectural Agricultural Experiment Station, Dr. M. Furuya, Advanced Research Laboratory, Hitachi Ltd., and Dr. A. Nagatani, the Tokyo University, for their fruitful discussions, and Dr. S. Gouthu, RIKEN, for critical reading of the manuscript.

\section{REFERENCES}

1) C. H. Beckman: "The Nature of Wilt Diseases of Plants," APS Press, St. Paul, MN, pp. 129-148, 1987

2) R. J. Cook \& K. F. Baker: "The Nature and Practice of Biological Control of Plant Pathogens," APS, St. Paul, MN, p. 539, 1983

3) K. Ogawa \& H. Komada: JARQ 19, 20 (1985)

4) T. Arie, S. Namba, S. Yamashita, Y. Doi \& T. Kijima : Ann. Phythpathol. Soc. Jpn. 53, 531 (1987)

5) H. Komada: Rev. Plant Protect. Res. 8, 114 (1975)

6) H. Komada: "Handbook of Soil-Borne Diseases (Complemently Revised Edition)," ed. by Editorial Committee for Handbook of Soil-Borne Diseases, Japan Plant Protection Association, Tokyo, pp. 234-236, 1984

7) T. Matuo: "Fusarium Diseases of Clutivated Plants," Zenkoku Noson Kyoiku Kyokai Publishing, Tokyo, p. 364, 1980

8) R. K. Lankow, G. D. Grothaus \& S. A. Miller : "Biotechnology in Agricultural Chemistry, ACS Symposium Series 334," ed. by H. M. LeBaron, et al., American Chemical Society, Washington, D.C., pp. 228-252, 1987

9) S. A. Miller \& R. R. Martin : Annu. Rev. Phytopathol. 26, 409 (1988)

10) L. W. Timmer, J. A. Menge, S. E. Zitko, E. Pono, A. Miller \& E. L. V. Johnson: Plant Dis. 77, 791 (1993)
11) E. Kimishima, S. Miyajima \& T. Shirakawa: Res. Bull. Plant. Prot. Serv. Jpn. 29, 37 (1993)

12) D. M. Cahill \& A. R. Hardham: Phytopathology 84, 193 (1994)

13) S. Takenaka \& M. Arai : Can. J. Bot. 71, 757 (1993)

14) G. H. Yuen, M. L. Craig \& F. Avila: Plant Dis. 77, 692 (1993)

15) T. Arie, S. Namba, S. Yamashita \& Y. Doi : Ann. Phytopathol. Soc. Jpn. 54, 242 (1988)

16) L. Lange, M. Heide, L. Hobolth \& L. W. Oslon : Phytopathology 79, 1066 (1989)

17) A. J. Wakeham \& J. G. White: Physiol. Mol. Plant Pathol. 48, 289 (1996)

18) T. Arie, Y. Hayashi, K. Yoneyama, A. Nagatani, M. Furuya \& I. Yamaguchi : Ann. Phytopathol. Soc. Jpn. 61, $311(1995)$

19) T. Arie, Y. Hayashi, A. Nagatani, M. Furuya \& I. Yamaguchi : Ann. Phytopathol. Soc. Jpn. 57, 696 (1991)

20) S. M. Nash \& W. C. Snyder : Phytopathology 52, 567 (1962)

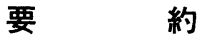

新しい免疫学的手法, gel penetrate-blotted immunobinding assay による土壤中の Fusarium spp.の検出

有江 力, 林 義雄, 米山勝美, 山口 勇 土猿中の Fusarium spp.の免疫学的検出法を新たに確立 した。 ニトロセルロースメンブレン上に厚さ約 $1 \mathrm{~mm}$ の寒 天ゲルを重ね，その寒天表面に土壌試料懸濁液を塗布する。 およそ10〜20 時間のインキュベーションの間に, 土壤サン プルに含まれる系状菌は土壌粒子と分離される。そのメカ ニズムは, 系状菌は菌系を伸長し，寒天ゲル層を貫通して メンブレンに達するが，一方で土㙵粒子は寒天表面に残存 することによる。こうして系状菌がブロットされたメンブ レンを,Fusarium 属菌に对して特異的に反応するモノク ローナル抗体 API9-2, 二次抗体, 基質の順で免疫学的に発 色させることで，ブロットされた糸状菌のうち，Fusarium spp.のみを検出できた。この方法を gel penetrate-blotted immunobinding assay (GP-IBA) と呼ぶこととした. 本法 によれば，24 時間以内に Fusarium 污染土壌を識別するこ とが可能であり, また, その検出可能な最小密度は $10^{3}$ 個分 生子 $/ \mathrm{g}$ 土㙵であり, 実際の最小発病単位と近似するため, 本方法が Fusarium spp.の検出に適していると考えられ た. 